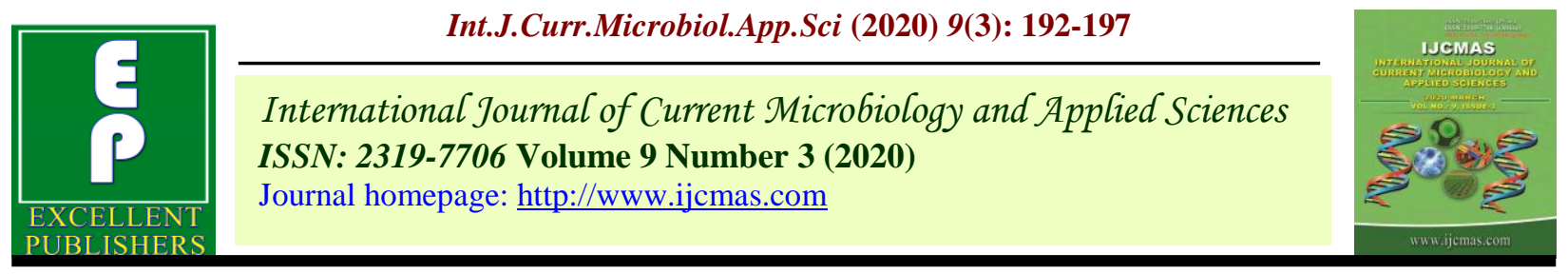

Original Research Article https://doi.org/10.20546/ijcmas.2020.903.023

\title{
Character association for yield parameters in Yam bean [Pachyrhizus erosus (L.) Urban]
}

\author{
Deep Shikha* and Ashish Narayan
}

Department of Plant Breeding and Genetics, TCA, Dholi, Dr. RPCAU, Pusa, Bihar, India

*Corresponding author

Keywords

Yam bean, germplasm, character association, yield parameters.

Article Info

Accepted:

05 February 2020

Available Online:

10 March 2020

A B S T R A C T

A field experiment was carried out with 28 yam bean germplasm along with 2 released variety namely Rajendra Misrikand-1(RM-1) and Rajendra Misrikand-2 (RM-2) laid out in a Randomised Block Design (RBD) with all recommended agronomic practices during kharif - 2017 and these genotypes have been studied for twelve different characters in association between seed and tuber yield and yield components. Tuber weight showed significant and positive correlation with tuber yield. Pods per plant and pod weight per plant exhibited significant and positive correlation with seed yield. Number of seeds per pod exhibited significant and positive correlation with pod length and pod weight per plant was found to have significant and positive correlation with pods per plant. Pods per plant exhibited significant and positive correlation with number of branches per plant. Such correlation indicates true relationship and thus assists in predicting tuber or seed yield.

\section{Introduction}

The Yam bean (Pachyrhizus spp.) is one of the legume root crops. Yam bean crop was introduced into India during the period between 1880 and 1890 (Anonymous 1889a; Tiwari et al., 1977). The main cultivation of the Yam bean takes place in parts of West Bengal, Assam, Bihar, Orissa and Andhra Pradesh. In India, it is most commonly grown in North Bihar including eastern Uttar Pradesh. The yam bean has bisexual flowers and is mainly self-pollinating. Yam beanis propagated by seed and needs to have the fertile shoots pruned repeatedly during the growing season in order to produce a higher tuber yield (Noda and Kerr 1983).

It has herbaceous vine with great variation in the outline of the leaflets, from dentate to palmate (Sorensen, 1996). Yam bean provides high tuber yields and as a legume it produces protein rich food and improves sustainability in cropping systems (NRC, 1979). The mature 
seeds of the yam bean are not used due to the high rotenone content (about $0.5 \%$ to $1 \%$ seed weight).

Correlation is the measure of degree and direction of association of one variable with other variable and determines how these characteristics vary together or whether there is any relationship between any two such characters.

\section{Materials and Methods}

The experimental material comprised of 30 germplasm accessions of yam bean [Pachyrhizus erosus (L.) Urban] including two released varieties, 'Rajendra Misrikand1' (RM-1) and 'Rajendra Misrikand-2' (RM2).

These genotypes were collected from the germplasm collection maintained at Dholi centre and the present investigation had been carried out at Dholi research farm of Dr.Rajendra Prasad Central Agricultural University, Pusa, and Bihar during kharif2017.The experiment was conducted in a randomised block design with three replications.

The characters studied were Plant height, Number of branches per plant, Days to $50 \%$ flowering, Pods per plant, Pod weight per plant, Pods per peduncle, Pod length, Number of seeds per pod, Tuber weight, Dry matter, Tuber yield and Seed yield.

Data for different characteristics were statistically analyzed for their association as per the standard methods. The plot had uniform topography, fertile and well-drained soil with subtropical climate of humid nature and is characterised by hot summer, moderate to heavy rainfall and cold winter. The rainfall is distributed mainly between middle of June to middle of October with average rainfall of about $1000 \mathrm{~mm}$ only.

\section{Results and Discussion}

The correlation at genotypic and phenotypic levels were computed from variance and covariance values for pairs of all the characters under study and has been presented in the Tables $1,2 \& 3$.

From the perusal of table 1, Tuber yield showed significant and positive correlation with tuber weight, indicating it as a single parameter for selection to increase tuber yield. Similar finding was reported by Nielson and Sorenson (2000) in yam bean and by Eze and Nwofia (2016) in Colocasia, that yield and yield associated traits observed significant positive association. Tuber yield was found to have positive association with plant height. Paul and Bari (2013) reported similar finding in Elephant Foot Yam.

However, tuber yield showed negative and non-significant association with seed yield indicating that both seed yield and tuber yield are not complementing each other. Similarly Akinyosoye et al., (2017) also reported that non-significant relationship existed between tuber and seed yield per plant. Tuber yield recorded negative association with pods per plant, pods per peduncle, number of seeds per pod and seed yield indicating that varieties should be developed in desired direction by considering these traits.

From the perusal of table 2, it is observed that, Seed yield showed significant and positive correlation with pods per plant and pod weight per plant. This indicates that germplasm showing high value for pods per plant and pod weight per plant will have increased seed yield.

Ojuederie et al., (2015) also reported similar finding, that a highly significant correlation was observed between seed yield and weight of total pods per plant. 
Table.1 Correlation between tuber yield and other characters

\begin{tabular}{|c|c|c|c|}
\hline \multirow[t]{2}{*}{ S.No. } & \multirow[t]{2}{*}{ Characters } & \multicolumn{2}{|c|}{ Correlation coefficient } \\
\hline & & Genotypic & Phenotypic \\
\hline 1. & Plant height $(\mathrm{cm})$ & 0.1250 & 0.1464 \\
\hline 2. & No. of branches per plant & 0.1881 & 0.1289 \\
\hline 3. & Days to $50 \%$ flowering & 0.4497 & 0.2973 \\
\hline 4. & Pods per plant & -0.0465 & -0.0394 \\
\hline 5. & Pod weight per plant (g) & 0.1537 & 0.1212 \\
\hline 6. & Pods per peduncle & -0.2493 & -0.1477 \\
\hline 7. & Pod length $(\mathrm{cm})$ & -0.0205 & -0.0090 \\
\hline 8. & No. of seeds per pod & 0.0028 & -0.0081 \\
\hline 9. & Tuber weight (g) & 0.7775 & $0.7363^{* *}$ \\
\hline 10. & Dry matter $(\%)$ & 0.2600 & 0.1898 \\
\hline 11. & Seed yield (kg/plot) & -0.3070 & -0.2624 \\
\hline
\end{tabular}

**Significant at $1 \%$ level

Table. 2 Correlation between seed yield and other characters

\begin{tabular}{|r|c|c|c|}
\hline \multirow{2}{*}{ S.No. } & Characters & \multicolumn{2}{|c|}{ Correlation coefficient } \\
\cline { 3 - 4 } & & Genotypic & Phenotypic \\
\hline $\mathbf{1 .}$ & Plant height $(\mathrm{cm})$ & -0.1133 & -0.0467 \\
\hline $\mathbf{2 .}$ & No. Of branches per plant & 0.0283 & 0.0906 \\
\hline $\mathbf{3 .}$ & Days to 50\% flowering & -0.3964 & -0.2643 \\
\hline $\mathbf{4 .}$ & Pods per plant & 0.6224 & $0.5072^{* *}$ \\
\hline $\mathbf{5 .}$ & Pod weight per plant (g) & 0.5904 & $0.4564^{* *}$ \\
\hline $\mathbf{6 .}$ & Pods per peduncle & 0.1369 & 0.0188 \\
\hline $\mathbf{7 .}$ & Pod length (cm) & 0.3760 & 0.2446 \\
\hline $\mathbf{8 .}$ & No. of seeds per pod & 0.1850 & 0.1872 \\
\hline $\mathbf{9 .}$ & Tuber weight $(\mathrm{g})$ & -0.2194 & -0.1621 \\
\hline $\mathbf{1 0 .}$ & Dry matter $(\%)$ & -0.0297 & -0.0594 \\
\hline $\mathbf{1 1}$ & Tuber yield (kg/plot) & -0.3070 & -0.2624 \\
\hline
\end{tabular}

**Significant at $1 \%$ level 
Table.3 Inter-relationship of tuber yield and seed yield attributing characters at phenotypic and genotypic level

\begin{tabular}{|c|c|c|c|c|c|c|c|c|c|c|c|c|c|}
\hline S.No. & Characters & & $\mathbf{P H}$ & NBPP & DFF & PoPP & PoWPP & PoPPe & PoL & NSPP & TW & DM & TY \\
\hline \multirow[t]{2}{*}{1.} & \multirow[t]{2}{*}{ Plant height $(\mathrm{cm})$} & $\mathrm{P}$ & 1.0000 & & & & & & & & & & \\
\hline & & G & 1.0000 & & & & & & & & & & \\
\hline \multirow[t]{2}{*}{2.} & \multirow[t]{2}{*}{ No. Of branches per plant } & $\mathrm{P}$ & 0.2408 & 1.0000 & & & & & & & & & \\
\hline & & G & 0.2369 & 1.0000 & & & & & & & & & \\
\hline \multirow[t]{2}{*}{3.} & \multirow[t]{2}{*}{ Days to $50 \%$ flowering } & $\mathrm{P}$ & -0.0665 & -0.0673 & 1.0000 & & & & & & & & \\
\hline & & $\mathrm{G}$ & -0.0401 & 0.1624 & 1.0000 & & & & & & & & \\
\hline \multirow[t]{2}{*}{4.} & \multirow[t]{2}{*}{ Pods per plant } & $\mathrm{P}$ & 0.2184 & $0.3322^{*}$ & -0.1564 & 1.0000 & & & & & & & \\
\hline & & $\mathrm{G}$ & 0.2564 & 0.5091 & -0.1997 & 1.0000 & & & & & & & \\
\hline \multirow[t]{2}{*}{5.} & \multirow[t]{2}{*}{ Pod weight per plant(g) } & $\mathrm{P}$ & 0.0782 & 0.2102 & -0.2364 & $0.4977^{* *}$ & 1.0000 & & & & & & \\
\hline & & $\mathrm{G}$ & 0.0620 & 0.3405 & -0.5394 & 0.5072 & 1.0000 & & & & & & \\
\hline \multirow[t]{2}{*}{6.} & \multirow[t]{2}{*}{ Pods per peduncle } & $\mathrm{P}$ & 0.0018 & 0.1543 & 0.1899 & 0.0424 & -0.0354 & 1.0000 & & & & & \\
\hline & & G & -0.2073 & 0.4247 & 0.3629 & -0.0306 & 0.0149 & 1.0000 & & & & & \\
\hline \multirow[t]{2}{*}{7.} & \multirow[t]{2}{*}{ Pod length $(\mathrm{cm})$} & $\mathrm{P}$ & 0.1610 & 0.1588 & 0.0319 & 0.1744 & 0.0471 & 0.2957 & 1.0000 & & & & \\
\hline & & G & 0.1253 & -0.0717 & -0.0097 & 0.3697 & 0.1112 & 0.6518 & 1.0000 & & & & \\
\hline \multirow[t]{2}{*}{8.} & \multirow[t]{2}{*}{ No. of seeds per pod } & $\mathrm{P}$ & 0.1571 & 0.0745 & 0.1404 & 0.2034 & 0.0105 & -0.1076 & $0.4216^{* *}$ & 1.0000 & & & \\
\hline & & $\mathrm{G}$ & 0.3215 & -0.2081 & 0.3660 & 0.3769 & 0.0110 & 0.0389 & 0.3954 & 1.0000 & & & \\
\hline \multirow[t]{2}{*}{9.} & \multirow[t]{2}{*}{ Tuber weight(g) } & $\mathrm{P}$ & 0.2514 & 0.0438 & 0.1961 & 0.0764 & 0.1935 & -0.1693 & -0.0777 & 0.0430 & 1.0000 & & \\
\hline & & G & 0.3147 & -0.0257 & 0.3084 & 0.0735 & 0.2329 & -0.2742 & -0.1447 & 0.0584 & 1.0000 & & \\
\hline \multirow[t]{2}{*}{10.} & \multirow[t]{2}{*}{ Dry matter (\%) } & $\mathrm{P}$ & -0.0565 & -0.1711 & 0.0660 & -0.0500 & -0.2256 & -0.0320 & 0.0671 & 0.0640 & 0.0684 & 1.0000 & \\
\hline & & G & 0.0376 & 0.0306 & -0.0250 & -0.0862 & -0.2185 & -0.1404 & 0.0171 & 0.1448 & 0.1788 & 1.0000 & \\
\hline \multirow[t]{2}{*}{11.} & \multirow[t]{2}{*}{ Tuber yield (kg/plot) } & $\mathrm{P}$ & 0.1464 & 0.1289 & 0.2973 & -0.0394 & 0.1212 & -0.1477 & -0.0090 & -0.0081 & $0.7363^{* *}$ & 0.1898 & 1.0000 \\
\hline & & $\mathrm{G}$ & 0.1250 & 0.1881 & 0.4497 & -0.0465 & 0.1537 & -0.2493 & -0.0205 & 0.0028 & 0.7775 & 0.2600 & 1.0000 \\
\hline \multirow[t]{2}{*}{12.} & \multirow[t]{2}{*}{ Seed yield (kg/plot) } & $\mathrm{P}$ & -0.0467 & 0.0906 & -0.2643 & $0.5072^{* *}$ & $0.4564^{* *}$ & 0.0188 & 0.2446 & 0.1872 & -0.1621 & -0.0594 & -0.2624 \\
\hline & & $\mathrm{G}$ & -0.1133 & 0.0283 & -0.3964 & 0.6224 & 0.5904 & 0.1369 & 0.3760 & 0.1850 & -0.2194 & -0.0297 & -0.3070 \\
\hline $\begin{array}{l}\mathrm{G}=\mathrm{C} \\
\mathrm{P}=\mathrm{P} \\
(*) \mathrm{Si}\end{array}$ & $\begin{array}{l}\text { typic correlation } \\
\text { typic correlation } \\
\text { cant at } 5 \% \text { level }\end{array}$ & & & & & & & & & & & & \\
\hline
\end{tabular}


Seed yield recorded negative association with plant height, days to $50 \%$ flowering, tuber weight, dry matter and tuber yield. Therefore, selection for long duration vigorous plants with good tuber yield will cost over seed yield.

The nature and magnitude of inter relationship among all character pairs were calculated at genotypic and phenotypic level to ascertain the inter relationship among the characters under study. Interrelationship among all twelve characters studied is presented in the Table 3.Dry matter recorded positive association with tuber yield. It also showed positive but non-significant association with Days to $50 \%$ flowering, Pod length and Number of seeds per pod. However, it showed negative and nonsignificant association with Plant height, Number of branches per plant, pods per plant, pod weight per plant and pods per Peduncle.Tuber weight showed positive but non-significant association with plant height, number of branches per plant, days to $50 \%$ flowering, pods per plant, pod weight per plant and number of seeds per pod. However, it was found to have negative but nonsignificant association with pods per peduncle and pod length.

Number of seeds per pod showed significant and positive association with pod length indicating that if pod length increases, number of seeds per pod also increases. Similar finding was reported by Popoola et al., (2011) in African yam bean and they reported that pod length was significantly correlated with number of seeds per pod. However, characters like plant height, number of branches per plant, days to $50 \%$ flowering, pods per plant and pod weight per plant were found to have positive but non-significant correlation with number of seeds per pod, while pods per peduncle showed negative and non-significant association. Pod length was found to have positive but non-significant association with plant height, number of branches per plant, days to $50 \%$ flowering, pods per plant, pod weight per plant and pods per peduncle showing their relationship with each other.

Pods per peduncle showed positive but nonsignificant association with plant height, number of branches per plant, days to $50 \%$ flowering and pods per plant while pod weight per plant showed negative and nonsignificant association. Pod weight per plant was found to have positive and significant association with pods per plant. However, characters like plant height and number of branches per plant showed positive but nonsignificant correlation while days to $50 \%$ flowering showed negative and nonsignificant correlation.

Pods per plant showed significant and positive association with number of branches plant while positive but non-significant association with plant height. However, it showed negative and non-significant association with days to $50 \%$ flowering. In the present investigation, days to $50 \%$ flowering showed negative and nonsignificant association with plant height and number of branches per plant. Number of branches per plant was found to have positive but non-significant association with plant height.

Therefore, it could be concluded that tuber yield had positive significant association tuber weight and seed yield had positive and significant association with pods per plant and pod weight per plant. Hence, selection for any of these characters would bring in simultaneous improvement of respective yield. 


\section{References}

Akinyosoye, S.T., Adetumbi, J.A., Amusa, O.D., Agbeleye, A., Anjorin, F., Olowolafe, M.O. and Omodele, T.(2017). Bivariate analysis of the genetic variability among some accessions of African Yam Bean (Sphenostylis stenocarpa (Hochst ex A. Rich) Harms). Acta Agriculturae Slovenica.109(3): 493 - 507

Eze, C.E. and Nwofia, G.E.(2016). Variability and Inter-Relationships between Yield and Associated Traits in Taro (Colocasia esculenta (L.) Schott). Journal of Experimental Agriculture International.14(2): 1-13.

National Research Council (NRC). (1979). Tropical Legumes: Resources for the Future. National Academy of Sciences Press, Washington, D.C.

Nielsen, P.E. and Sorensen, M. (2000). Yield potential of yam bean [Pachyrhizus erosus(L.) Urban] accessions in the kingdom of Tonga, South Pacific. Tropical Agriculture (Trinidad). 77(3):174-179.

Noda, H. and Kerr, W.E., (1983). The effects of staking and inflorescence pruning on the root production of Yam Bean (Pachyrrhizus erosus Urban). Trop. Grain Leg. Bull.27: 35-37.

Nwofia, G.E., Awaraka, R.O. and Agbo, C.U.
(2013). Genetic Variability and Trait Association Studies in African Yam Bean (Sphenostylis sternocarpa) Hochst ex A. Rich. American-Eurasian J. Agric. \& Environ. Sci. 13(11): 15471553.

Ojuederie, O.B., Balogun, M.O., Akande,S.K., Korie, S. and Omodele, T. (2015). Intraspecific Variability in Agro-Morphological Traits of African Yam Bean (Sphenostylis stenocarpa (Hochst ex. A. Rich) Harms). J. Crop Sci. Biotech.18(2): 53-62.

Popoola, J.O., Adegbite, A.E., Obembe, O.O. and Agbolade, J.O.(2011). Reproductive mechanisms and pollen characterization in some accessions of an underutilized legume: (Sphenostylis stenocarpa Hochst Ex. A. Rich) harms. International Journal of Biodiversity and Conservation. 3(6): 185-192.

Singh, S.K. and Tripathi, S.M.(2012). Genetical Studies on Zimikand (Amorphophallus campanulatus Blume.). Hort. Flora Research Spectrum.1(1): 77-79.

Sørensen, M. (1996). Yam bean (Pachyrhizus DC.). Promoting the conservation and use of underutilized and neglected crops. 2. Institute of Plant Genetics and Crop plant Research, Gatersleben/ International Plant Genetic Resources Institute, Rome.

\section{How to cite this article:}

Deep Shikha and Ashish Narayan. 2020. Character association for yield parameters in Yam bean [Pachyrhizus erosus (L.) Urban]. Int.J.Curr.Microbiol.App.Sci. 9(03): 192-197. doi: https://doi.org/10.20546/ijcmas.2020.903.023 